\title{
Mutual Fund Performance : Stock Selection or Market Timing?
}

\author{
Moh. Benny Alexandri \\ Universitas Padjadjaran \\ bennyalexandri@yahoo.co.id
}

\begin{abstract}
The number of mutual fund investors in Indonesia as an emerging market in compared with the population of Indonesia is very small. In the United States, mutual funds have become part of a family, where in 10 families, 8 have invested in mutual funds. While in Indonesia is still needs more time to achieve that conditions.
\end{abstract}

There is not many study about Investment Manager's Stock Selection and Market Timing Ability in Indonesia. Good ability of investment managers, will influence the performance of mutual funds.

This study aims to determine investment manager ability of the stock selection and market timing of equity funds in Indonesia,andthe most dominant factor affecting the performance

\section{INTRODUCTION}

Since 2008 global economic crisis, Indonesia government push number of investors in Indonesia,especially mutual fund investors. In October 2012, the number of mutual fund investors are still about 150 thousand people. Total funds aroundIDR. 170 trillion. This number is still very small compared to the number of customers ofbank. Bank managed fund reached to IDR. 2,984 trillion(August 2012).

Number of mutual fund investors in Indonesia, compared to the population is also very small. In the United States (US), mutual funds have become part of the family, where 8 to 10 families have invested in mutual funds.

Compare to the Indonesia's gross domestic product (GDP), mutual funds still small. In 2011, the percentage of investment is only 2.2 percent from total GDP (IDR. 7427 trillion). Compareto other countries in Southeast Asia, such as Malaysia (49\%), Thailand (20\%) and the Philippines (19.5\%), Indonesia needs more work harder to boost investor's participation.

Compareto the growth of the middle class phenomenon in Indonesia(reached 134 million people), number of mutual fund investors are still relatively small which only 150 thousand investors, (only $0.2 \%$ ). One of the characteristics of the middle class is "need for investments".

Mutual fund marketed by banks since 2003 in Indonesia. Nearly $60 \%$ of marketing mutual funds is through banks. Constraints from this condition is, a conflict of interest between the banking goals to market its products with to market mutual funds, even bank has a thoughts that mutual of mutual funds in Indonesia..Data used is for period 1/1/2008 31/3 / 2011. This study will prove whether

Manager Ability of Market Timing and Stock Selection is the most dominant variable in comparison with other variables associated with the performance of mutual funds in Indonesia.

The findings of this studyare Stock selection ability is the main reason for investor to choose mutual fund. Market timing will use by investor as main reason for invest, in the future.

The result of having a relation between stock selection, market timing ability and fund performance in an emerging market clearly warrant future studies.

Keyword : Mutual Fund, Stock Selection, Market Timing, Investment Manager

funds can reduce the motivation of bank customers to make deposits.

The next contraintin is mutual fund still only market for large funds investors. For example BNI Bank Tbk (National Bank) sell mutual funds only to priority customers withIDR. 1 billion minimum balance. The bank reason is related to the risk management and educational level of their customers.

Performance of mutual fund is a major consideration for investor in determining investment decisions. Fund performance is affected by many factors, known as the characteristics of mutual funds or determinants of mutual funds.

Characteristics of mutual fund which affectedby performance of mutual funds, divided into three, (1) investment manager, for example, gender, experience, graduates and so on. (2). factor of mutual funds, such as age, size of the fund, the type of mutual funds, mutual funds and so on purpose. (3) Factors of investor behavior.

In other study, the level of confidence of investors invest their funds in mutual funds is influenced by investor confidence in the ability of investment managers who manage their funds. Investment Company Report in the United States foundthat the motives of choice of a mutual fund in US are the performance of mutual funds (69\%), cost ratio(43\%) Investment manager profile (25\%). How is the condition in Indonesia?

Ability of stock selection and market timing has not been studied in Indonesia. In many studies, good ability of investment managers will result in a good performance to the performance of mutual funds. 
This study has a unique value which the amount of stock selection is used to indicate the ability of investment managers in Indonesia as an emerging market which is associated with the company's performance. This study is unique because ofusing mutual fund industry data in 2008 economic crisis.

The purpose of this study is: 1 . How does the investment manager ability of the stock selection and market timing of equity funds in Indonesia.2. Which is more dominant factor affecting the performance of mutual funds in Indonesia.

The reminder of the paper is organized as follows. Section II discussesthe literature review. and methodology.Section III contains the results. Section IV concludes with someimplications and areas for future research and finally section Vreferences.

\section{METHODOLOGY}

Research characteristics derived from the "Investment Manager", for example, Wermers (2003) are the behavior and style manager. Kon and Jen (1979), Kon S (1983), Chang and Lewellen (1984), Lee and Rahman (1990), Annuar et al (1997), Filipas and Psoma (2001), Christensen et al (2005), Rozali et al (2005), Swinkels (2008), are the ability of the manager on stock selection and market timing. Grant (1977), are market timing.

Sharpe (1966) are among the early researchers of the mutual fund. Sharpe, Treynor Index test in calculating the performance of mutual funds, also helped incorporate the characteristic of mutual funds in the calculation of performance. Sharpe found that mutual funds that charge is too large, it will cause a decrease in the performance of mutual funds.

A study conducted in the United States and published by the Financial Analysts Journal suggests that the rate of return on a portfolio, $91 \%$ was the accuracy of the allocation. Second, is the selection of investment instruments (bonds or bond $\mathrm{x} y$ ) also greatly affects the performance of mutual funds and the third , Market Timing, which is the time of purchase of investment instruments is one of the important factors for improving the performance of a portfolio or mutual funds.

This study is a Explanatory Survey Method to test the hypothesis that has been formulated previously. Although the description contains a description, but as a quantitative research focus in the explanation of the relationship between variables.

This study uses the verification method to reveal the relationship between the variables through hypothesis testing and it is also intended to determine the condition of each variable corresponding time period used in the study. Therefore, this type of research is explanatory verificative. (Sekaran, 2003).

Based on the purpose of this study, there are three (3) variables that need to be operationalized as follows:
(1) Stock Selection is an investment manager's ability to choose to form a portfolio of assets that are expected to provide the expected return in the future. Kon (1983). Stock Selection is an independent denoted as X1.

(2) Market Timing is a measure of the ability of the portfolio manager in anticipation of changes in the market where the market will decline when the manager changed the composition of its management portfolio securities to lower volatility and vice versa. Market Timing denoted as $\mathrm{X} 2$.

(3) Mutual Fund Performance, Sharpe Index developed by William Sharpe and is often referred to as the Reward-to-Variability Ratio (RVAR). Sharpe is the calculation on the concept of the Capital Market Line (capital market line) as a marker guess,itis by dividing the portfolio risk premium to the standard deviation. Sharpe Index is a dependent variable and denoted as Y.

In this study, the data sources used as a data analysis of the research is the net asset value (NAV), Bank Indonesia Certificates, Value Composite Stock Price Index (CSPI) derived from secondary data exchange is documented by IDX. In addition, the data can be obtained through direct investment managers, through IDX website, investment manager's website or through publications such as the newspaper (Bisnis Indonesia and Investor Magazine).

The process of research data sampling is purposive random sampling method. Sample are 37 (thirty-seven) mutual funds. The sample in this study is an equity fund that is published in January 2008 and still in operation in March 2011. If equity funds do not meet these requirements, the equity funds can not be used as a sample The number of mutual fund shares recorded until by March 2011 is as much as 74 mutual funds.

\section{RESULT}

\section{Stock Selection $\left(\mathbf{X}_{1}\right)$}

The ability of investment managers in selecting the right stocks in the portfolio can be demonstrated by the ability of stock selection. There are several methods in selecting the stocks in the portfolio composition. One common method is to choose stocks that on average provide performance that is "safe". The performance of some of these stocks can make the overall performance remains high, although in the bad economic conditions. Another method is by follow the foreign investment managers who are more experienced and has a good track investments.

Another method for measuring the Stock Selection is taking into account the level of performance compared to the performance of the market and the risk-free performance and beta. Treynor and Mazuy (1966) tried to use the model to 
calculate the CAPM Jensen and stock selection ability of investment managers. By using this model, it can be described ability of investment managers in selecting the right stocks.

According Treynor and Mazuy (1966) that when the value of (a) or positive alpha means that there is the ability selectivity and when the value of (b) or positive market timing means indicates the ability of market timing, then this indicates that the investment managers generate excess portfolio performance mutual danayang greater than the excess performance of the market.

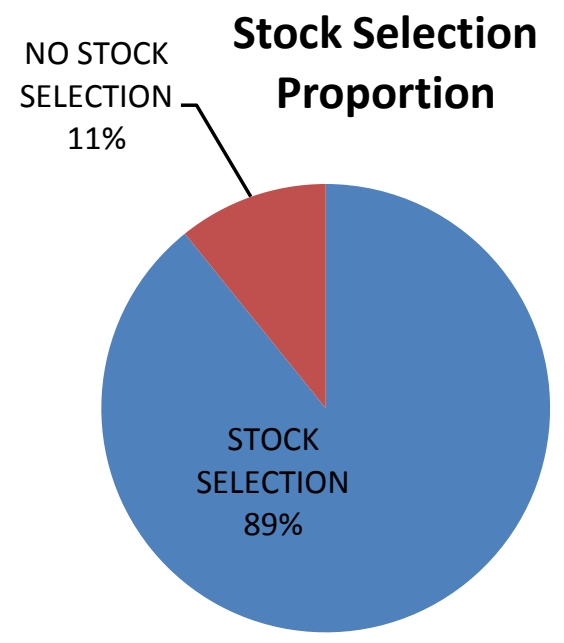

FIGURE A. Proportion Mutual Fund's Stock Selection Ability

In the picture above, in Indonesia, there has been a stock selection as much as $89 \%$, while the rest is no stock-selection.

\section{Market Timing $\left(\mathbf{X}_{2}\right)$}

Investment literature generally stated that market timing is very difficult to do, so many investment managers often rely on stock picking ability to obtain abnormal performance (superior).
To separate the two types of investment managers' ability, Treynor-Mazuy and Henriksson-Merton modifying Jensen alpha models. Investment management capabilities can be demonstrated by the ability of market timing. By using the formula Treynor and Mazuy, it can be described in the investment manager's ability to enter the market at the right time.

Positive values describe the ability of a manager to enter the market. 


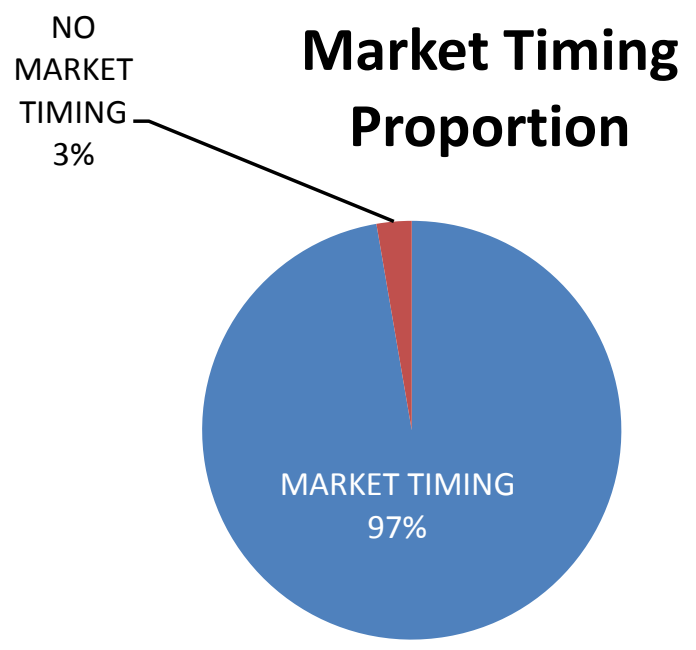

FIGURE B. The proportion of Stock Fund Market Timing Ability

\section{Mutual Fund Performance (Sharpe Index (Y))}

In the picture above, in Indonesia, there has been a market timing as much as $97 \%$, while the rest is nomarket timing.
The movement of the stock fund performance as indicated by the average value of the Sharpe Index shown in the picture below:

\section{Sharpe Index}

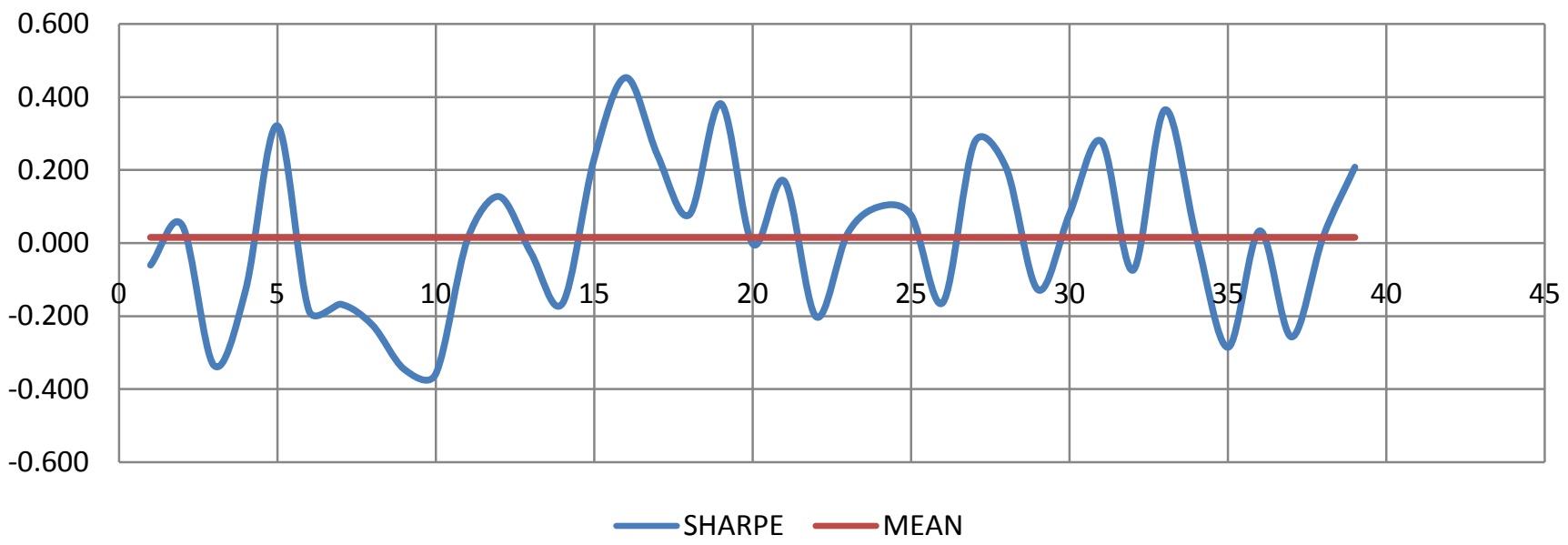

FIGURE C. Average Sharpe Index period 1/1/2008- 31/3/2011

In October 2008 (0-5), there were the general economic decline. One reason was of the United States economic crisis impact to Indonesian economy, including mutual funds in Indonesia.

\section{Regression Model Estimation and Hypothesis Testing}


To answer all the questions contained in the problem formulation used econometric methods to estimate the fixed effect econometric model as follows:

the results of the regression can be shown by Table A. below:

Table A.

Regression results

\begin{tabular}{|l|r|r|r|}
\hline & Coefficient & \multicolumn{1}{c|}{ t-Statistic } & Prob. \\
\hline Stock Selection & 0.154144 & 16.04691 & $* * *$ \\
\hline Market Timing & -0.261749 & -27.61387 & $* * *$ \\
\hline & & & \\
\hline $\mathbf{R}^{2}$ & 0.508067 & & \\
\hline Adjusted R2 & 0.492947 & & \\
\cline { 1 - 2 } F Satistic & 33.60196 & & \\
\cline { 1 - 3 } Durbin Watson Stat & 1.948861 & & \\
\cline { 1 - 3 }
\end{tabular}

- Significantat $\mathrm{a}=10 \% * *$ Significantat $\mathrm{a}=5 \% * * *$ Significantat $\mathrm{a}=1 \%$

- Stock Selection has a t-stat of 16.04691 whose value is greater than t-table $(2.577, \mathrm{a}=0.01)$, , so the hypothesis Ho is rejected. It can be concluded that the partial Stock Selection variable statistically affect fund performance in level of confidence of $99 \%$.

\section{DISCUSSION}

1. Variable Stock Selection has a value of 0.154144 , which value is significant at $99 \%$ confidence level. These results illustrate that the equity funds in Indonesia has illustrated of the investment manager's ability to pick stocks of mutual funds. In Indonesia, the investment manager using stock selection as a priority in deciding the investment product.

2. Variable market timing has a value of 0.261749 , which value is significant at $99 \%$
- Market Timing has a t-stat of -27.61387 whose value is smaller than the t-table $(-2.577, \mathrm{a}=0.01)$, , so the hypothesis Ho is rejected. It can be concluded that the partial Market Timing variables statistically affect fund performance in level of confidence of $99 \%$.

confidence level. But its value is negative which indicates precisely that the ability of market timing will cause decreased performance.

3. The securities company will be using stock selection as the dominant factor in preparing their portfolios. While it is only a complementary market timing as gains alone. The Company considers that the stock selection is the most fundamental factor of influence, while the market timing is of technical factors.

TABLE A.

Comparison Testing Hypotheses

\begin{tabular}{|l|c|c|c|}
\hline & Hypothesis & Result & Conclusion \\
\hline Stock Selection & $(+) /(-)$ & $(+)$ & appropriate \\
\hline Market Timing & $(+) /(-)$ & $(-)$ & appropriate \\
\hline
\end{tabular}

Based on regression analysis using panel data analysis, obtained dominant variables that affect the performance of mutual funds. When sorted, the dominant variable in influencing the performance of mutual funds is shown by the table below: 
Table B.

Variable Dominant based Standardized Regression Results

\begin{tabular}{|l|r|r|r|r|}
\hline \multicolumn{1}{|c|}{ Variable } & Coefficient & Std. Error & t-Statistic & \multicolumn{1}{c|}{ Prob. } \\
\hline Market Timing? & -0.41922 & 0.01518 & -27.6175 & 0 \\
\hline Stock Selection? & 0.256859 & 0.015987 & 16.06672 & 0 \\
\hline AGE? & 0.079627 & 0.033895 & 2.3492 & 0.019 \\
\hline SD? & -0.03561 & 0.017166 & -2.07447 & 0.0382 \\
\hline EXPENSE? & -0.06966 & 0.021002 & -3.31698 & 0.0009 \\
\hline
\end{tabular}

Market Timing and Stock Selection are the most dominant variable in comparison with other variables associated with the performance of mutual funds.

Market timing, although as dominant factor in influencing the performance of mutual funds, show a negative. This illustrates not need expertise in the investment manager to enter the market when buying and selling mutual funds. In some studies, the ability of market timing is the technical ability of mutual funds. Technical capability means the ability of investment manager or fund manager in entering the market in accordance with the movement of stock prices in the past.

Credit Susisse Securities Research and Analytics in a report Sept. 13 2012, said the main strategy of investing in equity

\section{References}

Chang, E And W. Lewellen,(1984), Market Timing And Mutual Fund Investment Performance, The Journal Of Business, p. 57-72

Christensen, M.,(2005), Danish Mutual Fund Performance : Selectivity, Market Timing and Persistence. Department of Accounting, Finance and Logistics, Aarhus School of Business, p. 1-39 funds in emerging markets is stock selection. Even for some of the emerging market countries such as Indonesia, stock selection is a very important factor.

Indonesia is a country with great volatility so at great risk. In addition, Indonesia is the country with an important level of stock selection. It is one of the reasons is the growth rate of Indonesia's large middle class in the last three years. Compare with the Philippines that although both the countries in Southeast Asia, but Philippines has had a large middle class for a long time. So for the Philippine stock selection is not so important in investing in mutual funds.

Filippas, N.D and Psoma.C, (2001), Equity Mutual Fund Managers Performance In Greece, Managerial Finance, Volume 27 Number 6 2001, p. 68-74.

Lee, C.F., Rahman, S. ,(1990), Market Selectivity and Mutual Fund Performance : An Empirical Investigation, The Journal of Business, Vol. 63. No.2, p 261-278.

Kon,S. ,(1983), "The Market Timing Performance Of Mutual Fund Managers, The Journal Of Business,56,p. 323347.

Kon, S.J, And Jen, F.C., (1979), The Investment Performance Of Mutual Funds : An Empirical Investigation Of Timing, Selectivity And Market Efficiency, Journal Of Business 52 (2): p. 263-89. 
Kon, S ,(1983), The Market Timing Performance of Mutual

Fund Managers, The Journal of Business, Vol 56, p. 323-347.

Rozali, M. B, (2006), Market Timing and Security Selection

Performance of Mutual Funds :Evidence From Malaysia.

Sekaran, Uma ,(2003), Research Methods for Business, A Skill Building Approach, Fourth Edition, John Wiley \& Sons, New York.

Sharpe, William, (1964), Capital Asset Prices : A Theory of Market Equilibrium under Condition of Risk, Journal of Finance, p 425-42.

Sharpe, W.,(1966)., Mutual Fund Performance, Journal of Business, Vol. 39, p. 119-138.

Swinkels, L.,(2008), Performance Evaluation of Polish Mutual Fund Managers, http//ssrn.com. p. 1-23

Treynor J., Mazuy K.,(1966), Can Mutual Funds Outguess The Market, Harvard Business Review, vol. 44, p136.
TinurFajarGumilangdanHeruSubiyantoro , ,2008), ReksadanaPendapatanTetap di Indonesia: Analisis Market Timing dan Stock Selection - Periode 2006 2008, JurnalKeuangandanMoneter; BadanKebijakanFiskal; DepartemenKeuangan: Vol. 11 (1); April 2008; p. 114-146.

Volkman, D., (1999),Market Volatility And Perverse Timing Performance Of Mutual Fund Managers,"The Journal Of Financial Research,22, p. 449-470

Wermers, R., (2000) ,Mutual Fund Performance : An Empirical Decomposition Into Stock-Picking Talent, Style, Transactions Costs And Expenses, Journal Of Finance, 55, p. 1655-1695

Wang Y.W,(2007), Are Busy Mutual Fund Portfolio Manager Better Managers?p.1-19

Yamane, Taro (1973), Elementary Sampling Theory, PrenticeHall. 